\title{
Memory CD4 T cell-mediated immunity against influenza A virus: more than a little helpful
}

\author{
K. Kai McKinstry ${ }^{1,}$, Richard W. Dutton ${ }^{1}$, Susan L. Swain ${ }^{1}$, and Tara M. Strutt ${ }^{1}$ \\ ${ }^{1}$ Department of Pathology, University of Massachusetts Medical School, 55 Lake Avenue North, \\ Worcester, Massachusetts, 01583, USA
}

\section{Abstract}

Recent observations have uncovered multiple pathways whereby CD4 T cells can contribute to protective immune responses against microbial threats. Incorporating the generation of memory CD4 T cells into vaccine strategies thus presents an attractive approach towards improving immunity against several important human pathogens, especially those against which antibody responses alone are inadequate to confer long-term immunity. Here, we review how memory CD4 $\mathrm{T}$ cells provide protection against influenza viruses. We discuss the complexities of protective memory CD4 T cell responses observed in animal models and the potential challenges of translating these observations into the clinic. Specifically, we concentrate on how better understanding organ-specific heterogeneity of responding cells and defining multiple correlates of protection might improve vaccine-generated memory CD4 $\mathrm{T}$ cells to better protect against seasonal, and more importantly, pandemic influenza.

\section{Introduction}

Successful vaccination against communicable disease has for the most part relied on the generation of long-lived antibodies able to rapidly neutralize invading pathogens and thus prevent infection in immunized individuals (Amanna and Slifka 2010; Elgueta et al. 2010). This basic approach, however, is of limited use with regards to several prominent pathogens against which neutralizing antibodies alone cannot confer long-term protection (Plotkin 2005). These include intracellular bacterial pathogens such as Mycobacterium tuberculosis, parasites with complex lifecycles including Plasmodium, and RNA viruses such as HIV, that can rapidly mutate to avoid recognition by circulating antibody.

While vaccination against influenza is widespread, influenza viruses also fall into this category of pathogens because of their rapid evolution and extensive host range, causing viral strains with novel surface proteins to arise each year (Taubenberger and Kash 2010). Thus, new annual vaccine formulations based on the surface protein expression of predicted circulating strains are required for efficient vaccine-induced protection. As current influenza vaccines also work largely through the generation of neutralizing antibodies, they can fail to provide protection when predictions as to circulating strains are incorrect. More importantly, such vaccination is not protective against pandemic influenza, and the challenges involved in the large-scale production of a neutralizing antibody-based vaccine specific for an outbreak virus may limit its efficacy (Hessel 2009).

One approach to improve vaccination against pathogens such as influenza A virus (IAV) is through generating strong memory $\mathrm{T}$ cell responses in addition to antibody (Schotsaert et al.

*Corresponding Author: Department of Pathology University of Massachusetts Medical School 55 Lake Avenue North Worcester, MA, 01655 Phone: 508-856-4499 kai.mckinstry@ mail.umassmed.edu. 
2012). As we have discussed previously, the generation of memory CD4 T cells in particular represents an attractive strategy as memory $\mathrm{CD} 4 \mathrm{~T}$ cells can regulate the responses of innate immune cells, of antibody-producing B cells, and of cytotoxic CD8 T cells, in addition to directly combating pathogens (Swain et al. 2012).

Animal models have contributed significantly to understanding how IAV causes disease and how successful immunity operates (Bouvier and Lowen 2010). Mice are the most commonly utilized mammalian host used, offering researchers an unparalleled range of reagents and inbred strains with which to define, isolate, and test the importance of distinct cellular subsets, as well as individual cytokines and chemokines, in contributing to disease and protection (O'Donnell and Subbarao 2011). However, the mouse is not a natural host for IAV, making it a poor model with which to study certain aspects of infection, notably viral transmission, and infection does not accurately replicate key clinical symptoms observed in humans (O'Donnell and Subbarao 2011). In contrast, the ferret model of IAV more accurately recapitulates viral transmission and clinical symptoms associated with human IAV infection, but has significant drawbacks compared to the mouse including increased cost, limitation on available reagents, and the outbred nature of laboratory ferrets (Belser et al. 2011)). Several other mammalian models of IAV have been developed, including the guinea pig (Lowen et al. 2006), cotton rat (Eichelberger 2007), non-human primate (Rimmelzwaan et al. 2003). While each of these models offers distinct advantages and disadvantages, the mouse allows for mechanistic studies not currently feasible in other hosts, making it an extremely powerful model with which to identify novel correlates of protection that could be applicable to human disease.

Recent observations in mice suggest that memory CD4 $\mathrm{T}$ cells can protect against IAV through multiple, distinct mechanisms and have also revealed an unexpected degree of heterogeneity in their response. Strong IAV-specific CD4 T cell responses have been correlated with protection in humans (Wilkinson et al. 2012). Here, we review recent observations highlighting the protective potential of memory CD4 T cells in mouse models of IAV infection, discuss their relevance to vaccination strategies, and point out some challenges of defining correlates of the most protective $\mathrm{T}$ cells in humans.

\section{Homotypic and Heterosubtypic immunity to IAV}

IAV is an enveloped RNA virus containing eight negative-sense segments that code for 11 viral proteins (Palese and Shaw 2007). The most important viral products in terms of the immune response against IAV are the surface glycoproteins hemagglutinin (HA) and neuraminidase (NA). These proteins are used to characterize IAV subtypes and are the major targets of neutralizing and protective antibody. Thus, annual vaccine formulations aim largely to generate high titers of neutralizing HA-specific IgG antibodies that will be present prior to natural exposure and thereby prevent infection. This is the basis of so-called 'homotypic' immunity that has been readily demonstrated in animal models since the 1930's (Francis and Magill 1935). The longevity of homotypic immunity is impressive: an analysis of survivors from the 1918 IAV epidemic showed evidence of strong humoral immunity nearly 90 years after exposure to the virus (Yu et al. 2008). The efficacy of such vaccination against IAV outside of the laboratory is, however, short-lived due to the antigenic variability of the viral HA and NA proteins in circulating strains driven through two distinct mechanisms (Treanor 2004). The first, antigenic shift, results when a protein from one virus is replaced with one from another subtype of IAV. Antigenic shift can result in the emergence of pandemic strains when the substituted HA has not circulated in the human population for some time. 
The second mechanism that leads to antigenic change in IAV, antigenic drift, is caused by point mutations in viral proteins. Antigenic drift is driven largely by antibody-mediated selective pressure, highlighting the critical role of the humoral response in homotypic immunity (Yewdell 2011). Thus analysis of a broad range of human IAV isolates revealed that the internal viral proteins, shielded from antibody recognition, are largely conserved between isolates while the external proteins HA and NA demonstrated a remarkable degree of heterogeneity (Powell et al. 2007; Miotto et al. 2008). However, while antigenic drift contributes to the limitation of long-term vaccine-induced humoral immunity, the identification of broadly neutralizing antibodies, able to recognize conserved epitopes of surface proteins across multiple IAV strains, holds strong potential as a basis for novel vaccination strategies able to confer 'universal' protection, or as a powerful therapeutic tool when conventional vaccine-induced protection is inadequate (Dreyfus et al. 2012; Ekiert et al. 2011; Corti et al. 2011; Wei et al. 2010).

An additional, distinct form of immunity against IAV was first identified in the mid-1960's (Schulman and Kilbourne 1965) when it was shown that animals primed with one IAV strain were protected against a subsequent challenge with a strain expressing different external proteins (HA and NA). This protection was, in contrast to homotypic protection, not transferable to naïve animals by serum antibody. Instead, such 'heterosubtypic' protection relies largely on the response of memory $\mathrm{T}$ cells specific for the internal proteins of IAV that are largely conserved between strains (Liang et al. 1994; Powell et al. 2007; Suguitan et al. 2006). In contrast to homotypic immunity, which can prevent re-infection through antibodymediated neutralization of virus, heterosubtypic immunity cannot prevent initial infection, as IAV-specific T cells must recognize virally derived peptide antigen in the context of MHC molecules presented by infected cells in order to respond (Figure 1).

In contrast to readily evident observations of homotypic immunity, evidence of robust heterosubtypic immunity in human populations has only recently begun to emerge. It is possible that the impact of heterosubtypic protection in humans has been underappreciated in many studies that simply measure the presence or absence of virus in individuals at a given time point because heterosubtypic protection does not prevent infection, but does lead to earlier clearance of virus (Dutton et al. 2007). The substantiation of heterosubtypic immunity in humans in more recent clinical studies has been helped to a large degree by recent well-documented outbreaks of pandemic IAV and extensive clinical and epidemiological data (McKinstry et al. 2011; Hillaire et al. 2011).

\section{Heterosubtypic Immunities?}

Understanding the cellular requirements for optimal heterosubtypic immunity against IAV in animal models has proven challenging. We have previously discussed the body of somewhat perplexing findings describing mutually exclusive requirements for IAV-primed CD4 T cells, CD8 T cells, and B cells in mediating such protection (McKinstry et al. 2011). These studies, and our more recent observations (McKinstry et al. 2012), suggest that several forms of heterosubtypic immunity can be generated in response to infection or vaccination that rely more or less heavily on specific types of primed IAV-specific cells. Whether B cells, CD4 T cells, or CD8 T cells play a more important or less dramatic role in heterosubtypic immunity is likely influenced by many factors including the interval between priming and re-challenge, differences in the types of and doses of priming or challenge virus, as well as by differences in host genetic background.

On top of these variables defined in controlled laboratory studies, IAV infection in the human population adds further complexity. For example, the potential impact of previous infections with unrelated pathogens on the T cell repertoire able to recognize IAV; such 
heterologous infections can both narrow or broaden the reactive $\mathrm{T}$ cell pool within individuals, with important consequences for both T cell-mediated immunity and immunopathology (Selin et al. 2011). In addition, major correlates of vaccine-induced protection may differ significantly between age groups (Black et al. 2011; McElhaney and Dutz 2008). This is especially relevant for the very young and the elderly population - the two groups at most risk of the serious consequences of IAV infection.

More studies are required to better define how these and other variables impact the specific character of heterosubtypic protection. Such research might eventually allow for more accurate clinical determinants of a strong immune state against IAV, for example through systems approaches able to predict the relative importance of IAV-specific humoral and cellular immunity within individuals through an integration of measures rather than defining only total virus-specific IgG or hemagglutination inhibition titers, or quantifying only virusspecific T cells by ELISPOT or tetramer assay (Lambert et al. 2012). We will next concentrate on how memory CD4 T cells can impact protection against IAV and how recent observations have impacted our thinking as to how their generation might improve vaccine efficacy. We will also discuss some of the major problems that translation from animal models to the clinic might present.

\section{The naïve CD4 T cell response to IAV}

Several studies in animal models have addressed how CD4 T cells are activated by IAV, and how their response contributes to protection. Naïve CD4 T cells recognizing virus are activated in the draining mediastinal lymph nodes during the first few days following intranasal infection and develop into highly differentiated effectors that traffic to the infected lung, peaking in number by about 7-8 days post-infection. These primary effectors most resemble prototypical 'Th1' effectors as they produce high levels of IFN $\gamma$ as well as lower levels of IL-2 and TNF (Strutt et al. 2012). In addition, many CD4 T cells responding in the lung, but not in the spleen or draining lymph nodes, produce IL-10. This IL-10 production is largely restricted to a subset of effector cells co-producing IFN $\gamma$ (McKinstry et al. 2009; Sun et al. 2009). Interestingly, IL-10 production by IAV-specific CD4 T cells can blunt protective responses (Sun et al. 2010), especially through restraining Th17-associated cytokine production (McKinstry et al. 2009), but has also been shown to limit excessive immunopathology (Sun et al. 2009).

An intriguing feature of the primary CD4 T cell response to IAV is the high degree of functional and phenotypic heterogeneity observed between cells responding in the spleen, draining lymph node, and lung (Roman et al. 2002). We will discuss in more detail elements of this heterogeneity and its implications further on. Perhaps surprisingly, the CD4 T cell response is generally dispensable for viral clearance during primary infection. It is worth noting, however, that CD4 T cells are absolutely required for the generation of long-lived protective antibody against IAV (Kamperschroer et al. 2006). The B cell helper activity of CD4 T cells is critically dependent on CD4 T cell expression of the protein SAP (Kamperschroer et al. 2008), consistent with the function of specialized follicular helper CD4 T cells $\left(\mathrm{T}_{\mathrm{FH}}\right)$ (Crotty 2011). Thus, while IAV does generate a robust $\mathrm{T}$ cellindependent antibody response (Waffarn and Baumgarth 2011) that contributes to viral clearance in the absence of CD4 T cell help, the levels of such antibodies decline to substantially lower levels within 14-21 days (Kamperschroer et al. 2006). This results in an inability of CD4 T cell-deficient mice reconstituted with SAP-deficient CD4 T cells recognizing IAV to mount strong homotypic immunity in contrast to animals receiving the same number of wild-type (WT) cells. 
In contrast to help for B cell antibody production, studies have found no role for CD4 T cell help in shaping the primary CD8 T cell response during IAV challenge (Tripp et al. 1995;

Seah et al. 2012). Thus, the major protective role for the CD4 T cell response during primary infection with IAV, as is the case for several other viral infections, seems to the provision of B cell help.

\section{Memory CD4 $\mathrm{T}$ cells and protection against IAV}

The large majority of virus-specific effector CD4 T cells die following viral clearance, leaving a small number of memory cells that persist long-term (McKinstry et al. 2010b). In contrast to the naïve CD4 T cell response, the memory CD4 T cell response against IAV can profoundly impact protection. We and others have shown that the transfer of memory CD4 T cells recognizing IAV, including TcR Tg cells recognizing aa 110-119 (Kirberg et al. 1994) or 126-138 (Scott et al. 1994) of the A/PR8 HA protein, or bulk polyclonal memory CD4 T cell populations obtained from IAV-primed mice, to otherwise unprimed mice can protect adoptive hosts from lethal and even supra-lethal challenges (Teijaro et al. 2010; McKinstry et al. 2012; Strutt et al. 2012). In contrast, a recent study concluded that the transfer of physiological numbers of memory CD4 T cells to unprimed mice resulted in minimal protection (Thomas et al. 2010). Determining the physiological number of IAV-specific physiological memory CD4 T cells is, however, extremely difficult due to the diversity of viral epitopes recognized (Richards et al. 2011) and that the most immunodominant MHC II-restricted peptides in mice only make up about $10 \%$ or less of the total response, depending on the strain of mouse (Nayak et al. 2010; Crowe et al. 2006). It is thus possible that this latter study might have observed a protective impact with the transfer of slightly higher numbers of memory CD4 T cells, as their protective impact is titratable (McKinstry et al. 2012). Together, these observations suggest that memory CD4 T cell-mediated protection against IAV, though potent, might wane significantly with time after priming, as memory CD4 T cell numbers decay more rapidly following the resolution of primary immune responses than memory CD8 T cells (Seder and Ahmed 2003).

\section{Synergizing mechanisms of protection}

Remarkably, we have uncovered multiple discrete forms of immunity against IAV mediated by memory CD $4 \mathrm{~T}$ cells by systematically deconstructing protective memory CD4 T celldependent responses through the use of T cell-, B cell-, or T and B cell-deficient mouse models (Boonnak and Subbarao 2012). First, we transferred memory CD4 T cells to unprimed WT mice or mice deficient for either B cells or T cells (Table 1). We observed that memory cells protected WT mice from doses of 10,000 EID50 of the highly pathogenic mouse-adapted IAV strain A/PR8 (Tate et al. 2011) (about 2 LD50 for WT mice), while protection in hosts lacking either B cells or T cells was significantly impaired (McKinstry et al. 2012). Nevertheless, memory cell transfer did protect B or T cell-deficient mice against lower, but still lethal doses of $2500 \mathrm{EID}_{50}$ (McKinstry et al. 2012). These results demonstrate that protection mediated by memory CD4 T cells against IAV is optimal in the presence of both naïve B cells and other $\mathrm{T}$ cells, reinforcing the potent anti-viral activity of both IAV-specific antibody produced by B cells and of cytotoxic CD8 T cell responses.

Indeed, further studies utilizing removal of CD8 T cells by administration of depleting antibodies revealed that memory CD4 T cell protection and viral clearance in B celldeficient hosts required the presence of CD8 T cells during the viral clearance phase (McKinstry et al. 2012). Thus, CD8 T cells and memory CD4 T cell responses synergize to clear virus efficiently, but memory CD4 T cells could not synergize with naïve CD4 T cells to protect. This finding is consistent with previous studies showing that adoptive transfer of even large numbers of naïve IAV-specific CD4 T cells to unprimed mice cannot confer protection (Brown et al. 2006). 
We could not identify a helper role for the primary CD8 response performed by memory CD4 T cells, consistent with previous studies (Tripp et al. 1995; Seah et al. 2012), suggesting that the protective synergy operates at the level of the distinct effector functions provided by memory CD4 and naïve CD8 T cells, and not necessarily synergistic interactions between the two cell types.

Using a similar reductionist approach, we verified that viral clearance mediated by memory CD4 T cells in T cell-deficient hosts required the production of IAV-specific antibody. A relatively low amount of IAV-specific IgG, when transferred to immunodeficient mice receiving memory $\mathrm{CD} 4 \mathrm{~T}$ cells, a level of antibody which did not provide protection on its own, could synergize with the memory CD4 T cells to completely clear the virus (McKinstry et al. 2012). These results are in line with earlier studies from Gerhard's laboratory finding protective synergy between naïve B cells and IAV-specific CD4 T cell clones (Scherle and Gerhard 1986). Perhaps surprisingly, we could not find a role for major germinal center B cell helper pathways in the protective synergy between memory CD4 T cells and naïve B cells as the transfer of SAP-deficient CD4 T cells provided identical protection to WT memory cells, and the disruption of CD40:CD40L interactions using blocking antibody also did not impair protection (McKinstry et al. 2012). Although, consistent with previous studies (Kamperschroer et al. 2006; Lee et al. 2005), disruptions of both SAP- and CD40L-dependent signaling did diminish levels of long-lived circulating IAV-specific IgG (McKinstry et al. 2012). We plan further studies to determine whether the memory CD4 T cells in this model are providing a form of early extra-follicular help for antibody production (Elsner et al. 2012), or whether the T cell-independent antibody response generated by IAV infection is sufficient to synergize with protective memory CD4 $\mathrm{T}$ cells. Thus, these results suggest that the canonical $\mathrm{T}_{\mathrm{FH}}$-associated germinal center $\mathrm{B}$ cell helper activity of memory CD4 T cells, which in other viral disease models is a critical protective function (Swain et al. 2012), is largely dispensable for heterosubtypic immunity against IAV.

This finding fits nicely with observations that viral clearance in heterosubtypic challenge models can occur by 7 days post-infection, a time point that precedes or is coincident with the first detectable serum antibody response to the heterosubtypic challenge virus (Powell et al. 2007; Strutt et al. 2012). Similar observations have been made in non-human primates primed with a seasonal H1N1 virus and challenged with the 2009 pandemic H1N1 virus. In this model, protection correlated with robust $\mathrm{T}$ cell responses generated by seasonal H1N1 priming and clearance of the pandemic virus challenge occurred before the appearance of neutralizing antibody directed against the pandemic challenge virus (Weinfurter et al. 2011). These observations, however, do not rule out a protective role for non-neutralizing IAVspecific antibody generated during the primary response during heterosubtypic immunity. Studies in reductionist mouse models have indeed identified the potential for a strong protective contribution from non-neutralizing IgG against the highly conserved viral nucleoprotein during heterosubtypic challenge (LaMere et al. 2011).

\section{Direct mechanisms of protection}

In addition to synergistic mechanisms of protection, we also indentified direct mechanisms of viral clearance mediated by memory CD4 T cells by utilizing lymphocyte-deficient SCID mice (lacking B and T cells) as hosts (Table 1). When transferred to SCID mice challenged with the same dose of virus as utilized in the studies described above, memory CD4 T cells initially controlled viral titers leading to recovery of weight loss, but virus rebounded during the second week of infection and all mice eventually succumbed (McKinstry et al. 2012). This again highlights the importance of memory CD4 T cell synergy with CD8 T cells and B cells for protection. However, when we infected SCID hosts with lower, but still lethal doses, memory CD4 $\mathrm{T}$ cells could protect and efficiently clear virus. This protection was 
completely dependent on IFN $\gamma$, as memory cells deficient in IFN $\gamma$ production, or administration of IFN $\gamma$-blocking antibody to SCID mice receiving WT memory CD4 T cells abolished protection (McKinstry et al. 2012). Thus, we hypothesize that direct control of IAV by memory CD4 $\mathrm{T}$ cells is largely IFN $\gamma$-dependent, and likely operates through the induction of an antiviral state in lung epithelial cells combined with the mobilization of elements of the innate immune system. We plan further studies to investigate whether and which innate immune cells are critical for this IFN $\gamma$-dependent protection. Candidate populations include APC subsets, neutrophils, and NK cells, all of which can be activated by IFN $\gamma$ and all of which have been shown to contribute to protection against IAV (Tate et al. 2010; Tate et al. 2009; Ge et al. 2012; Ishikawa et al. 2010; Dienz et al. 2012; Huang et al. 2011).

Interestingly, however, we could discern no protective role for IFN $\gamma$ in memory CD4 T cellmediated protection of WT, B cell-, or T cell-deficient hosts (Table 1). Indeed, complete protection was restored in SCID mice receiving IFN $\gamma$-deficient memory CD4 T cells by the cotransfer of either naïve B or CD8 T cells from IFN $\gamma$-deficient mice, while the transfer of either population alone was not protective (McKinstry et al. 2012). Thus, while the ability to produce IFN $\gamma$ is indeed a correlate of protection for memory CD4 T cells, this direct mechanism of protection can be superseded by synergies with other IAV-specific lymphocytes that operate in an IFN $\gamma$-independent manner.

Studies from our laboratory have also identified that CD4 T cell effectors can utilize a perforin-dependent cytolytic mechanism to combat IAV, presumably by lysing virallyinfected epithelial cells in a MCH II-dependent manner (Brown et al. 2006; Brown et al. 2012). We observed that memory CD4 T cells also control IAV titers in a perforindependent manner (McKinstry et al. 2012). This mechanism of protection was not readily observed in the presence of protective synergies of memory CD4 T cells with B cells or CD8 T cells, exactly as was the case for direct control involving IFN $\gamma$ (Table 1).

In addition to mediating viral control, we observed that a perforin-dependent mechanism was responsible for the selection of epitope-specific viral escape mutants that arose in SCID mice in a TCR-dependent manner (McKinstry et al. 2012). Thus, memory CD4 T cells recognizing the HNT epitope of the HA of the A/PR8 virus selected for isolates that contained mutations in the HNT epitope while memory cells recognizing a peptide of ovalbumin protein (OVA) drove mutations in a virus expressing the relevant OVA peptide in the HA (A/PR8-OVA $\left.A_{I I}\right)$ only at the DO11.10 peptide insertion site but not in the HNT epitope. Previous studies have demonstrated that a similar mechanism is employed by IAVspecific CD8 T cells to drive the emergence of escape mutants, consistent with this subset's major role in viral clearance through CTL activity (Price et al. 2000; Price et al. 2005). That CD4 T cells can also drive viral escape underscores their ability to directly contribute to viral clearance. Future studies will be required to elucidate whether and how viral selection driven by CD4 $\mathrm{T}$ cell responses can impact the outcome of IAV infection. While this mechanism likely does not contribute to the evolution of IAV circulating within a population, escape from a defined human CD4 T cell epitope has been described (Berkhoff et al. 2007), and could profoundly impact individual cases.

\section{The complexity of protection and defining cellular correlates of protection}

The studies summarized above reveal the potential of enhancing vaccine-induced protection against IAV by targeting the generation of memory CD4 T cells in addition to neutralizing antibodies. However they also introduce the problem of how vaccine efficacy and the strength of antiviral CD4 T cell memory should be evaluated. Specifically, they suggest that 
since multiple forms of protective immunity can be engaged by memory CD4 T cells, multiple correlates of protection may have to be considered.

For example, the most commonly utilized measures to enumerate and characterize protective memory CD4 $\mathrm{T}$ cells are IFN $\gamma$ production assays. But since memory cells can protect through synergy with B or CD8 T cells in an IFN $\gamma$-independent manner, this measure alone is an inadequate indicator of their potential efficacy during recall challenge. Similar caveats likely apply to measures of memory CD4 T cell cytotoxic capacity or of B cell helper functions.

Interestingly, we have also found evidence of multiple redundant mechanisms of protection operating during CD8 T cell effector responses against IAV. In these studies, we found that the individual removal of the major protective mechanisms associated with effector CD8 T cells including perforin, FAS and TRAIL-mediated killing, as well as IFN $\gamma$ production, did not eliminate their protective capacity. This suggests that although most often considered solely as cytotoxic killers of virally infected cells, memory CD8 T cells can also contribute to viral clearance through multiple, distinct pathways (Hamada et al. 2013).

\section{Naïve vs. Memory CD4 T cell responses to IAV}

Why can memory CD4 T cells protect against IAV while naïve CD4 T cells cannot? A defining feature of the primed state against a given pathogen is an increase in the number of antigen-specific $\mathrm{T}$ cells. It is also appreciated that memory CD4 T cells are less dependent on costimulation and can respond optimally to lower levels of TCR stimulation than naïve cells (London et al. 2000; McKinstry et al. 2010a; Dutton et al. 1998). We tested the importance of these two defining qualities of the memory state in protection against IAV mediated by memory CD4 T cells. We transferred equal numbers of naïve or memory CD4 $\mathrm{T}$ cells recognizing IAV to unprimed hosts and rigorously assessed the response of both populations (Table 2). In earlier studies, we focused on acute events following infection and observed that memory, but not naïve CD4 T cells, drove an enhanced inflammatory response that contributed to viral control (Strutt et al. 2010). This response occurred within 48 hours of infection, similar to observations from Topham's group (Chapman et al. 2011), before any memory cell division. We have discussed the protective capacity of this acute memory CD4 T cell-enhanced inflammatory response in the lung at length elsewhere (Strutt et al. 2011). These results demonstrate that important functional differences distinguish naïve and memory cells, and suggest that these functional differences, and not just numerical differences, may play underscore the protective capacity of memory CD4 T cells.

Are the unique actions of memory versus naïve CD4 T cells that occur within the first few days following infection responsible for protection? In addition to their ability to enhance protective inflammatory responses in lung during 2-4 days post-infection, experiments both in the IAV model (Strutt et al. 2012) and in others (MacLeod et al. 2011) have demonstrated that memory CD4 $\mathrm{T}$ cells are also superior helpers for B cell antibody responses compared to naïve cells. This B cell helper function also operates within the first 5-6 days of IAV challenge. However, when we specifically depleted protective donor memory cells responding in adoptive hosts 5 days after challenge, we observed that protection was lost even though help for antibody production and upregulation of innate immunity were already evident (Strutt et al. 2012). These results suggest that late events mediated by memory CD4 $\mathrm{T}$ cells, occurring after 5 days post-infection in the IAV model, are also critical for protection. We therefore analyzed the response of highly divided effector cells derived from naïve (primary effector) or memory (secondary effectors) precursors to ask whether functional differences could also distinguish these populations, and if so, whether they were important in memory CD4 $\mathrm{T}$ cell-mediated protection against IAV. 
We transferred the same number of naïve or memory CD4 T cells specific for IAV to unprimed mice and challenged with virus. Interestingly, both populations developed into highly activated effectors with similar kinetics, and reached similar peak numbers in the spleen and draining lymph nodes by 7 days post-infection (Strutt et al. 2012). In contrast, memory cells gave rise to populations of secondary effectors in the lung that were 5-10-fold higher in number than primary effectors arising from naïve cells. A strikingly increased magnitude of secondary versus primary CD4 T cell effectors upon IAV challenge has also recently been observed in a similar model (Luthje et al. 2012). As the secondary CD4 T cell effector response during recall challenge in intact primed mice generally does not reach levels 10-fold above primary effector responses, it suggests that regulatory mechanisms must limit the magnitude of secondary CD4 T cell effectors in primed animals. Work from Doherty's group supports this hypothesis, and points towards important regulation by primed CD8 T cells on the size of the secondary CD4 T cell effector response in the lung (Thomas et al. 2010). The regulatory impact of primed CD8 T cells on the size of secondary CD4 T cell expansion might operate by lowering viral titers, as we observed a strong correlation between the peak number of secondary CD4 T cell effectors in the lung with increasing viral load (unpublished observations).

We next assessed the functional capacity of both effectors and found that secondary effectors contained more multi-cytokine producing cells when we assayed for the major cytokines produced during T cell responses against IAV, namely IFN $\gamma$, TNF, and IL-2 (Strutt et al. 2012). This pattern of increased multi-cytokine production in secondary effectors was observed in all organs tested. In addition, secondary effectors produced more IL-17 and less IL-10. The correlation of enhanced IL-17 and decreased IL-10 production correlating with protective $\mathrm{T}$ cell responses against IAV fits well with our previous studies (McKinstry et al. 2009). These findings also support the general concept introduced by Seder and colleagues that $\mathrm{T}$ cells able to co-produce multiple cytokines offer better protection than those that produce only IFN $\gamma$ (Seder et al. 2008).

However, while we and others have investigated the impact of IFN $\gamma$, IL-10, and IL-17 during IAV challenge, more studies are needed to define whether TNF and IL-2 mediate protective or detrimental roles during IAV infection. IL-2 is thought to act as a critical autocrine growth factor, but this view is largely based on in vitro data; $\mathrm{T}$ cell responses in vivo are often not much impacted by IL-2-deficiency (Malek 2008). More recent data suggests that IL-2 can act as a potent pro-inflammatory mediator in specific tissues, including the lung (Sharma et al. 2011). These observations point towards the possibility that IL-2 could have a positive impact on maximizing protective CD4 T cell response against IAV while also contributing to enhanced immunopathology. We are actively investigating these possibilities, and previous results do indeed suggest that the memory CD4 T cell response against IAV can mediate substantial immunopathology (Teijaro et al. 2009). Studies of how TNF impacts murine IAV infection have also lead to contradictory results. One body of evidence suggests that TNF plays a detrimental, pro-inflammatory role during infection (Perrone et al. 2010; Xu et al. 2004), and it is a prime factor in the 'cytokine storm' associated with highly pathogenic IAV (Salomon et al. 2007). On the other hand, a recent study concludes that TNF instead serves a surprisingly important anti-inflammatory role during IAV challenge (Damjanovic et al. 2011). Clearly, a more complete understanding of the roles of important CD4 T cell-derived cytokines during the IAV infection is important for ultimately generating $\mathrm{T}$ cells with the most protective functions through vaccination. 


\section{Organ-specific heterogeneity of responding effectors}

In order to more completely understand the $\mathrm{CD} 4 \mathrm{~T}$ cell response against IAV, we rigorously compared highly differentiated effectors found in the spleen, draining lymph nodes, and lung by whole genome microarray. We noted extensive differences in gene expression were largely shared by primary and secondary CD4 T cell effectors (Strutt et al. 2012). These differences suggest the possibility of the simultaneous development of effector populations at different anatomical sites that are specialized for different functions. Indeed, when we compared genes expressed by lung-resident effectors compared to those in secondary lymphoid organs, we observed enrichment for several genes involved in anti-viral responses and associated with cytotoxic killing (Strutt et al. 2012). This correlates well with the finding that cytotoxic function of CD4 T cell effectors during IAV challenge is largely confined to lung-resident cells (Brown et al. 2012). On the other hand, we observed that primary effectors in the spleen and draining lymph nodes were enriched for a panel of genes associated with $\mathrm{T}_{\mathrm{FH}}$ function. This we (Strutt et al. 2012), and others (Boyden et al. 2012), have confirmed with phenotypic analysis.

These results suggest that different correlates of protective immune responses may be defined in different organs due to the presence of T cells with specialized functions (i.e. B cell helper activity or cytotoxic function, and likely many others). Interestingly, however, we observed that secondary effectors contained a significant $\mathrm{T}_{\mathrm{FH}}$ population in the lung as well as in the spleen and draining lymph nodes. This suggests that secondary effector functions may be less compartmentalized compared to those of CD4 T cell effectors during the primary response, and we hypothesize that this might be a key element in the superior protective capacity of memory CD4 T cells.

\section{Where are the most protective memory CD4 T cells found?}

An important question that bears consideration based on the observations discussed above is where CD4 T cells in the peripheral blood would fit into the pattern of heterogeneity defined by cells isolated from the spleen, draining lymph nodes, and lung. As peripheral blood is almost exclusively the source of clinically studied $\mathrm{T}$ cells, it is possible that critical functional attributes of the most protective $\mathrm{T}$ cell subsets are missed because those cells are not present, or are only present in very low frequency, in the circulation.

What are the most protective CD4 T cells responding against IAV? We isolated primary or secondary effectors from either the lung or secondary lymphoid organs of mice and transferred equal numbers directly to new unprimed hosts that were then infected with IAV. We observed that secondary effectors provided a strong degree of protection whether isolated from the lung or secondary lymphoid organs, and that per-cell, their protective impact was superior to the same number of transferred primary effectors (Strutt et al. 2012). Thus, in addition to the enhanced magnitude of secondary versus primary effector responses derived from the same number of memory or naïve CD4 T cell precursors, respectively, the per-cell protective capacity of secondary effectors is also greater than that of primary effectors. This is consistent with the enhanced multifunctional potential of secondary versus primary effectors. However, primary effectors from the lung provided dramatically better protection compared to effectors from secondary lymphoid organs. This finding is in line with studies from Farber's group showing that memory CD4 T cells isolated from the lung provide enhanced protection upon adoptive transfer compared to cells isolated from the secondary lymphoid organs (Teijaro et al. 2011). While these experiments demonstrate superior protection provided by memory cells from the lung, they do not identify the critical protective mechanisms employed by these cells. Further studies will be required to ascertain 
the contributions of known protective functions such as IFN $\gamma$ production, cytotoxic function, or activation of innate defense pathways.

\section{Analyzing IAV-specific memory CD4 T cells in humans}

While recent studies utilizing mouse models of IAV infection highlight the potential for memory CD4 $\mathrm{T}$ cells to provide long-term protection by discrete mechanisms, several challenges exist in translating and validating these studies in the clinic. As it is impossible to systemically deconstruct the protective memory CD4 T cell response against IAV in humans to validate which mechanisms of CD4 T cell-mediated protection operate, and in what hierarchy they contribute to immunity, our results suggest that measuring as many CD4 T cell functions as possible will be required to screen the full capacity, and thus the likelihood, of vaccine-induced memory CD4 T cell ability to contribute to protection. For example, a recent study analyzed the capacity of IAV-specific CD4 T cells generated through vaccination to produce IFN $\gamma$, TNF, or IL-2 and correlated these responses with the degree of protective antibody responses (Pedersen et al. 2012). The development of powerful multiplex assays able to screen multiple functional attributes simultaneously holds promise for such analysis (Ge et al. 2010).

The heterogeneity of memory CD4 T cells responding to IAV in different organs suggests that even extensive analysis of CD4 T cells in the peripheral blood might be of limited value. Large numbers of memory CD4 T cells can be observed in human lungs (Purwar et al. 2011), a population of cells that, if observations in the mouse hold, might contain the most protective, and thus the most relevant IAV-specific memory CD4 T cells in terms of long-term protection. The development of novel approaches to screen for the presence and function of memory CD4 T cells specific for IAV and resident in the lung could unlock tremendous possibilities in vaccine development.

In addition, although studies have shown that memory CD4 T cells are remarkably multifunctional, reductionist approaches have demonstrated that, under different conditions, different functions gain or loose critical importance in mediating protection (McKinstry et al. 2012), suggesting that defining a universal correlate of optimal IAV-specific memory CD4 T cells will be difficult, if not impossible. Just because a cell can perform a function (for example cytolytic killing, IFN $\gamma$ production, or the provision of B cell help) does not necessarily mean that a given function is relevant (or the most relevant) to protection in a given context. Thus, the identification of more and better correlates of strong $\mathrm{T}$ cellmediated immunity against IAV, assessable in different organs through non-invasive methods, will be critical to better understand the potential of vaccine-generated CD4 T cellmediated immunity to protect against IAV in the human population.

\section{Concluding Remarks - How to improve vaccine-induced CD4 T cell immunity?}

Vaccine strategies incorporating the generation of memory CD4 T cells capable of providing strong heterosubtypic immunity hold the potential to dramatically reduce the burden of global IAV infection. Recent data from the clinic and observations in animal models suggest two key elements that might improve the induction of protective $\mathrm{T}$ cell memory.

First, in studies comparing the efficacy of inactivated or live attenuated IAV vaccines, it was found that the live attenuated vaccine induced superior $\mathrm{T}$ cell responses in mice (Chen et al. 2011), and in humans, especially in younger children (He et al. 2006; Forrest et al. 2008; Hoft et al. 2011), though commercially available trivalent inactivated vaccines can also induce a surprisingly broad repertoire of IAV-specific memory $\mathrm{T}$ cells (Richards et al. 
2012). These studies suggest that vaccine formulations, likely based on attenuated live viruses, may be further improved to maximize the induction of memory CD4+, and also CD8+ T cells. The use of pro-T cell-inducing adjuvants represents another strategy that might boost numbers of protective memory $\mathrm{CD} 4 \mathrm{~T}$ cell numbers generated through vaccination (Galli et al. 2009; Moris et al. 2011; Clegg et al. 2012; Pedersen et al. 2012; Surls et al. 2012).

In addition, a body of evidence, largely from Rimmelzwaan's group, suggests that annual vaccination with inactivated IAV vaccines may actually be detrimental to heterosubtypic immunity by curtailing natural seasonal infection that otherwise might elicit a stronger degree of cross-protective $\mathrm{T}$ cell memory (Bodewes et al. 2012), again suggesting that vaccines based on live attenuated viruses may provide broader and more potent $\mathrm{T}$ cell memory through improved $\mathrm{T}$ cell priming and boosting. Alternatively, $\mathrm{T}$ cell-based vaccines, for example utilizing other viral vectors encoding IAV proteins may be developed to target specifically the generation of CD4 T cells specific for conserved viral proteins, mirroring an approach that has proven successful in boosting IAV-specific CD8 T cell numbers in humans (Lillie et al. 2012). Thus, incorporating the generation of IAV-specific memory CD4 $\mathrm{T}$ cells as a goal of vaccination (in addition to the generation of antibody), and, as previously mentioned, uncovering clinically relevant functional or phenotypic correlates of the most protective CD4 T cells, may significantly improve the efficacy of vaccines to induce heterosubtypic immunity in humans.

Second, an exciting body of recent findings suggests that local, tissue-resident $\mathrm{T}$ cell memory may be required for optimal protection against pathogens that enter the body at mucosal sites (Bevan 2011; Sheridan and Lefrancois 2011; Swain et al. 2012). Thus, maximizing the generation and persistence of $\mathrm{T}$ cell memory specifically in the lung may dramatically improve vaccine-induced protection against IAV. Tissue-resident memory $\mathrm{T}$ cells usually require interactions of specific receptors with ligands in the local environment for their persistence. For example, Topham's group has identified a unique subset of lungresident memory CD4 $\mathrm{T}$ cells generated by IAV challenge that requires expression of the integrin VLA-1 in order to bind type IV collagen (Chapman and Topham 2010).

Observations highlight distinct requirements for the induction of local immunity in the lung versus systemic T cell responses following the delivery of live attenuated IAV vaccines (Lau et al. 2011), and highlight the importance of the route of immunization in inducing strong antibody and T cell-based immunity (Price et al. 2010).

The continued exploration of novel vaccination strategies better able to directly target the generation of local immunity in the lung holds tremendous promise (Song et al. 2010). Understanding what signals are most important in the generation of lung-resident memory CD4 T cells may lead to improved vaccine strategies better able to provide strong homotypic and, more importantly, heterosubtypic protection against IAV. And strategies that provide such $\mathrm{T}$ cell immunity are also likely to work with other viruses and pathogens for which current antibody-based vaccines fail to provide effective and long-lasting protection.

\section{Acknowledgments}

This work was supported by National Institutes of Health grants AI-46530 and NS-061014. We apologize to the many authors whose relevant work we could not discuss or reference due to space limitations. 


\section{References}

Amanna IJ, Slifka MK. Mechanisms that determine plasma cell lifespan and the duration of humoral immunity. Immunol Rev. 2010; 236:125-138. doi:IMR912 [pii] 10.1111/j.1600-065X. 2010.00912.x. [PubMed: 20636813]

Belser JA, Katz JM, Tumpey TM. The ferret as a model organism to study influenza A virus infection. Dis Model Mech. 2011; 4(5):575-579. doi:dmm.007823 [pii] 10.1242/dmm.007823. [PubMed: 21810904]

Berkhoff EG, Geelhoed-Mieras MM, Jonges M, Smith DJ, Fouchier RA, Osterhaus AD, Rimmelzwaan GF. An amino acid substitution in the influenza A virus hemagglutinin associated with escape from recognition by human virus-specific CD4+ T-cells. Virus Res. 2007; 126(1-2): 282-287. doi:S0168-1702(07)00058-5 [pii] 10.1016/j.virusres.2007.02.018. [PubMed: 17420064]

Bevan MJ. Memory T cells as an occupying force. Eur J Immunol. 2011; 41(5):1192-1195. doi: 10.1002/eji.201041377. [PubMed: 21469134]

Black S, Nicolay U, Vesikari T, Knuf M, Del Giudice G, Della Cioppa G, Tsai T, Clemens R, Rappuoli R. Hemagglutination inhibition antibody titers as a correlate of protection for inactivated influenza vaccines in children. Pediatr Infect Dis J. 2011; 30(12):1081-1085. doi:10.1097/INF. 0b013e3182367662. [PubMed: 21983214]

Bodewes R, Fraaij PL, Kreijtz JH, Geelhoed-Mieras MM, Fouchier RA, Osterhaus AD, Rimmelzwaan GF. Annual influenza vaccination affects the development of heterosubtypic immunity. Vaccine. 2012 doi:S0264-410X(12)00632-9 [pii] 10.1016/j.vaccine.2012.04.086.

Boonnak K, Subbarao K. Memory CD4+ T cells: beyond "helper” functions. J Clin Invest. 2012; 122(8):2768-2770. doi:65208 [pii] 10.1172/JCI65208. [PubMed: 22820285]

Bouvier NM, Lowen AC. Animal Models for Influenza Virus Pathogenesis and Transmission. Viruses. 2010; 2(8):1530-1563. doi:10.3390/v20801530. [PubMed: 21442033]

Boyden AW, Legge KL, Waldschmidt TJ. Pulmonary infection with influenza A virus induces sitespecific germinal center and T follicular helper cell responses. PLoS One. 2012; 7(7):e40733. doi: 10.1371/journal.pone.0040733 PONE-D-12-11121 [pii]. [PubMed: 22792401]

Brown DM, Dilzer AM, Meents DL, Swain SL. CD4 T cell-mediated protection from lethal influenza: perforin and antibody-mediated mechanisms give a one-two punch. J Immunol. 2006; 177(5): 2888-2898. doi:177/5/2888 [pii]. [PubMed: 16920924]

Brown DM, Lee S, Garcia-Hernandez MD, Swain SL. Multi-functional CD4 cells expressing IFNgamma and perforin mediate protection against lethal influenza infection. J Virol. 2012 doi:JVI. 07172-11 [pii] 10.1128/JVI.07172-11.

Chapman TJ, Lambert K, Topham DJ. Rapid reactivation of extralymphoid CD4 T cells during secondary infection. PLoS One. 2011; 6(5):e20493. doi:10.1371/journal.pone.0020493 PONED-10-01664 [pii]. [PubMed: 21647373]

Chapman TJ, Topham DJ. Identification of a unique population of tissue-memory CD4+ T cells in the airways after influenza infection that is dependent on the integrin VLA-1. J Immunol. 2010; 184(7):3841-3849. doi:jimmunol.0902281 [pii] 10.4049/jimmunol.0902281. [PubMed: 20200271]

Chen GL, Lau YF, Lamirande EW, McCall AW, Subbarao K. Seasonal influenza infection and live vaccine prime for a response to the 2009 pandemic H1N1 vaccine. Proc Natl Acad Sci U S A. 2011; 108(3):1140-1145. doi:1009908108 [pii] 10.1073/pnas.1009908108. [PubMed: 21199945]

Clegg CH, Roque R, Van Hoeven N, Perrone L, Baldwin SL, Rininger JA, Bowen RA, Reed SG. Adjuvant solution for pandemic influenza vaccine production. Proc Natl Acad Sci U S A. 2012 doi:1207308109 [pii] 10.1073/pnas.1207308109.

Corti D, Voss J, Gamblin SJ, Codoni G, Macagno A, Jarrossay D, Vachieri SG, Pinna D, Minola A, Vanzetta F, Silacci C, Fernandez-Rodriguez BM, Agatic G, Bianchi S, Giacchetto-Sasselli I, Calder L, Sallusto F, Collins P, Haire LF, Temperton N, Langedijk JP, Skehel JJ, Lanzavecchia A. A neutralizing antibody selected from plasma cells that binds to group 1 and group 2 influenza A hemagglutinins. Science. 2011; 333(6044):850-856. doi:science.1205669 [pii] 10.1126/science. 1205669. [PubMed: 21798894]

Crotty S. Follicular helper CD4 T cells (TFH). Annu Rev Immunol. 2011; 29:621-663. doi:10.1146/ annurev-immunol-031210-101400. [PubMed: 21314428] 
Crowe SR, Miller SC, Brown DM, Adams PS, Dutton RW, Harmsen AG, Lund FE, Randall TD, Swain SL, Woodland DL. Uneven distribution of MHC class II epitopes within the influenza virus. Vaccine. 2006; 24(4):457-467. doi:S0264-410X(05)00779-6 [pii] 10.1016/j.vaccine. 2005.07.096. [PubMed: 16140434]

Damjanovic D, Divangahi M, Kugathasan K, Small CL, Zganiacz A, Brown EG, Hogaboam CM, Gauldie J, Xing Z. Negative regulation of lung inflammation and immunopathology by TNF-alpha during acute influenza infection. Am J Pathol. 2011; 179(6):2963-2976. doi:S0002-9440(11)00850-9 [pii] 10.1016/j.ajpath.2011.09.003. [PubMed: 22001698]

Dienz O, Rud JG, Eaton SM, Lanthier PA, Burg E, Drew A, Bunn J, Suratt BT, Haynes L, Rincon M. Essential role of IL-6 in protection against H1N1 influenza virus by promoting neutrophil survival in the lung. Mucosal Immunol. 2012; 5(3):258-266. doi:mi20122 [pii] 10.1038/mi.2012.2. [PubMed: 22294047]

Dreyfus C, Laursen NS, Kwaks T, Zuijdgeest D, Khayat R, Ekiert DC, Lee JH, Metlagel Z, Bujny MV, Jongeneelen M, van der Vlugt R, Lamrani M, Korse HJ, Geelen E, Sahin O, Sieuwerts M, Brakenhoff JP, Vogels R, Li OT, Poon LL, Peiris M, Koudstaal W, Ward AB, Wilson IA, Goudsmit J, Friesen RH. Highly conserved protective epitopes on influenza B viruses. Science. 2012; 337(6100):1343-1348. doi:science.1222908 [pii] 10.1126/science.1222908. [PubMed: 22878502]

Dutton RW, Bradley LM, Swain SL. T cell memory. Annu Rev Immunol. 1998; 16:201-223. [PubMed: 9597129]

Dutton RW, Swain SL, Woodland DL. Vaccines against pandemic influenza. Viral Immunol. 2007; 20(2):326-327. doi:10.1089/vim.2007.0011. [PubMed: 17603849]

Eichelberger MC. The cotton rat as a model to study influenza pathogenesis and immunity. Viral Immunol. 2007; 20(2):243-249. doi:10.1089/vim.2007.0017. [PubMed: 17603841]

Ekiert DC, Friesen RH, Bhabha G, Kwaks T, Jongeneelen M, Yu W, Ophorst C, Cox F, Korse HJ, Brandenburg B, Vogels R, Brakenhoff JP, Kompier R, Koldijk MH, Cornelissen LA, Poon LL, Peiris M, Koudstaal W, Wilson IA, Goudsmit J. A highly conserved neutralizing epitope on group 2 influenza A viruses. Science. 2011; 333(6044):843-850. doi:science.1204839 [pii] 10.1126/ science.1204839. [PubMed: 21737702]

Elgueta R, de Vries VC, Noelle RJ. The immortality of humoral immunity. Immunol Rev. 2010; 236:139-150. doi:IMR924 [pii] 10.1111/j.1600-065X.2010.00924.x. [PubMed: 20636814]

Elsner RA, Ernst DN, Baumgarth N. Single and coexpression of CXCR4 and CXCR5 identifies CD4 T helper cells in distinct lymph node niches during influenza virus infection. J Virol. 2012; 86(13): 7146-7157. doi:JVI.06904-11 [pii] 10.1128/JVI.06904-11. [PubMed: 22532671]

Forrest BD, Pride MW, Dunning AJ, Capeding MR, Chotpitayasunondh T, Tam JS, Rappaport R, Eldridge JH, Gruber WC. Correlation of cellular immune responses with protection against culture-confirmed influenza virus in young children. Clin Vaccine Immunol. 2008; 15(7):10421053. doi:CVI.00397-07 [pii] 10.1128/CVI.00397-07. [PubMed: 18448618]

Francis T, Magill TP. Immunological Studies with the Virus of Influenza. J Exp Med. 1935; 62(4): 505-516. [PubMed: 19870430]

Galli G, Medini D, Borgogni E, Zedda L, Bardelli M, Malzone C, Nuti S, Tavarini S, Sammicheli C, Hilbert AK, Brauer V, Banzhoff A, Rappuoli R, Del Giudice G, Castellino F. Adjuvanted H5N1 vaccine induces early $\mathrm{CD} 4+\mathrm{T}$ cell response that predicts long-term persistence of protective antibody levels. Proc Natl Acad Sci U S A. 2009; 106(10):3877-3882. doi:0813390106 [pii] 10.1073/pnas.0813390106. [PubMed: 19237568]

Ge MQ, Ho AW, Tang Y, Wong KH, Chua BY, Gasser S, Kemeny DM. NK Cells Regulate CD8+ T Cell Priming and Dendritic Cell Migration during Influenza A Infection by IFN-gamma and Perforin-Dependent Mechanisms. J Immunol. 2012; 189(5):2099-2109. doi:jimmunol.1103474 [pii] 10.4049/jimmunol.1103474. [PubMed: 22869906]

Ge X, Gebe JA, Bollyky PL, James EA, Yang J, Stern LJ, Kwok WW. Peptide-MHC cellular microarray with innovative data analysis system for simultaneously detecting multiple CD4 T-cell responses. PLoS One. 2010; 5(6):e11355. doi:10.1371/journal.pone.0011355. [PubMed: 20634998]

Hamada H, Bassity E, Flies A, Strutt TM, Garcia-Hernandez Mde L, McKinstry KK, Zou T, Swain SL, Dutton RW. Multiple redundant effector mechanisms of CD8+ T cells protect against 
influenza infection. J Immunol. 2013; 190(1):296-306. doi:jimmunol.1200571 [pii] 10.4049/ jimmunol.1200571. [PubMed: 23197262]

He XS, Holmes TH, Zhang C, Mahmood K, Kemble GW, Lewis DB, Dekker CL, Greenberg HB, Arvin AM. Cellular immune responses in children and adults receiving inactivated or live attenuated influenza vaccines. J Virol. 2006; 80(23):11756-11766. doi:JVI.01460-06 [pii] 10.1128/JVI.01460-06. [PubMed: 16971435]

Hessel L. Pandemic influenza vaccines: meeting the supply, distribution and deployment challenges. Influenza Other Respi Viruses. 2009; 3(4):165-170. doi:IRV085 [pii] 10.1111/j. 1750-2659.2009.00085.x.

Hillaire ML, Osterhaus AD, Rimmelzwaan GF. Induction of virus-specific cytotoxic T lymphocytes as a basis for the development of broadly protective influenza vaccines. J Biomed Biotechnol. 2011; 2011:939860. doi:10.1155/2011/939860. [PubMed: 22007149]

Hoft DF, Babusis E, Worku S, Spencer CT, Lottenbach K, Truscott SM, Abate G, Sakala IG, Edwards KM, Creech CB, Gerber MA, Bernstein DI, Newman F, Graham I, Anderson EL, Belshe RB. Live and inactivated influenza vaccines induce similar humoral responses, but only live vaccines induce diverse T-cell responses in young children. J Infect Dis. 2011; 204(6):845-853. doi:jir436 [pii] 10.1093/infdis/jir436. [PubMed: 21846636]

Huang FF, Barnes PF, Feng Y, Donis R, Chroneos ZC, Idell S, Allen T, Perez DR, Whitsett JA, Dunussi-Joannopoulos K, Shams H. GM-CSF in the lung protects against lethal influenza infection. Am J Respir Crit Care Med. 2011; 184(2):259-268. doi:201012-2036OC [pii] 10.1164/ rccm.201012-2036OC. [PubMed: 21474645]

Ishikawa H, Tanaka K, Kutsukake E, Fukui T, Sasaki H, Hata A, Noda S, Matsumoto T. IFN-gamma production downstream of NKT cell activation in mice infected with influenza virus enhances the cytolytic activities of both NK cells and viral antigen-specific CD8+ T cells. Virology. 2010; 407(2):325-332. doi:S0042-6822(10)00560-X [pii] 10.1016/j.virol.2010.08.030. [PubMed: 20855097]

Kamperschroer C, Dibble JP, Meents DL, Schwartzberg PL, Swain SL. SAP is required for Th cell function and for immunity to influenza. J Immunol. 2006; 177(8):5317-5327. doi:177/8/5317 [pii]. [PubMed: 17015717]

Kamperschroer C, Roberts DM, Zhang Y, Weng NP, Swain SL. SAP enables T cells to help B cells by a mechanism distinct from Th cell programming or CD40 ligand regulation. J Immunol. 2008; 181(6):3994-4003. doi:181/6/3994 [pii]. [PubMed: 18768854]

Kirberg J, Baron A, Jakob S, Rolink A, Karjalainen K, von Boehmer H. Thymic selection of CD8+ single positive cells with a class II major histocompatibility complex-restricted receptor. J Exp Med. 1994; 180(1):25-34. [PubMed: 8006585]

Lambert ND, Ovsyannikova IG, Pankratz VS, Jacobson RM, Poland GA. Understanding the immune response to seasonal influenza vaccination in older adults: a systems biology approach. Expert Rev Vaccines. 2012; 11(8):985-994. doi:10.1586/erv.12.61. [PubMed: 23002979]

LaMere MW, Lam HT, Moquin A, Haynes L, Lund FE, Randall TD, Kaminski DA. Contributions of antinucleoprotein IgG to heterosubtypic immunity against influenza virus. J Immunol. 2011; 186(7):4331-4339. doi:jimmunol.1003057 [pii] 10.4049/jimmunol.1003057. [PubMed: 21357542]

Lau YF, Santos C, Torres-Velez FJ, Subbarao K. The magnitude of local immunity in the lungs of mice induced by live attenuated influenza vaccines is determined by local viral replication and induction of cytokines. J Virol. 2011; 85(1):76-85. doi:JVI.01564-10 [pii] 10.1128/JVI.01564-10. [PubMed: 20962087]

Lee BO, Rangel-Moreno J, Moyron-Quiroz JE, Hartson L, Makris M, Sprague F, Lund FE, Randall TD. CD4 T cell-independent antibody response promotes resolution of primary influenza infection and helps to prevent reinfection. J Immunol. 2005; 175(9):5827-5838. doi:175/9/5827 [pii]. [PubMed: 16237075]

Liang S, Mozdzanowska K, Palladino G, Gerhard W. Heterosubtypic immunity to influenza type A virus in mice. Effector mechanisms and their longevity. J Immunol. 1994; 152(4):1653-1661. [PubMed: 8120375]

Lillie PJ, Berthoud TK, Powell TJ, Lambe T, Mullarkey C, Spencer AJ, Hamill M, Peng Y, Blais ME, Duncan CJ, Sheehy SH, Havelock T, Faust SN, Williams RL, Gilbert A, Oxford J, Dong T, Hill AV, Gilbert SC. Preliminary assessment of the efficacy of a T-cell-based influenza vaccine, MVA- 
NP+M1, in humans. Clin Infect Dis. 2012; 55(1):19-25. doi:cis327 [pii] 10.1093/cid/cis327. [PubMed: 22441650]

London CA, Lodge MP, Abbas AK. Functional responses and costimulator dependence of memory CD4+ T cells. J Immunol. 2000; 164(1):265-272. [PubMed: 10605020]

Lowen AC, Mubareka S, Tumpey TM, Garcia-Sastre A, Palese P. The guinea pig as a transmission model for human influenza viruses. Proc Natl Acad Sci U S A. 2006; 103(26):9988-9992. doi: 0604157103 [pii] 10.1073/pnas.0604157103. [PubMed: 16785447]

Luthje K, Kallies A, Shimohakamada Y, GT TB, Light A, Tarlinton DM, Nutt SL. The development and fate of follicular helper T cells defined by an IL-21 reporter mouse. Nat Immunol. 2012; 13(5):491-498. doi:ni.2261 [pii] 10.1038/ni.2261. [PubMed: 22466669]

MacLeod MK, David A, McKee AS, Crawford F, Kappler JW, Marrack P. Memory CD4 T cells that express CXCR5 provide accelerated help to B cells. J Immunol. 2011; 186(5):2889-2896. doi:jimmunol.1002955 [pii] 10.4049/jimmunol.1002955. [PubMed: 21270407]

Malek TR. The biology of interleukin-2. Annu Rev Immunol. 2008; 26:453-479. doi:10.1146/ annurev.immunol.26.021607.090357. [PubMed: 18062768]

McElhaney JE, Dutz JP. Better influenza vaccines for older people: what will it take? J Infect Dis. 2008; 198(5):632-634. doi:10.1086/590435. [PubMed: 18652548]

McKinstry KK, Strutt TM, Buck A, Curtis JD, Dibble JP, Huston G, Tighe M, Hamada H, Sell S, Dutton RW, Swain SL. IL-10 deficiency unleashes an influenza-specific Th17 response and enhances survival against high-dose challenge. J Immunol. 2009; 182(12):7353-7363. doi: 182/12/7353 [pii] 10.4049/jimmunol.0900657. [PubMed: 19494257]

McKinstry KK, Strutt TM, Kuang Y, Brown DM, Sell S, Dutton RW, Swain SL. Memory CD4+ T cells protect against influenza through multiple synergizing mechanisms. J Clin Invest. 2012; 122(8):2847-2856. doi:63689 [pii] 10.1172/JCI63689. [PubMed: 22820287]

McKinstry KK, Strutt TM, Swain SL. The potential of CD4 T-cell memory. Immunology. 2010a; 130(1):1-9. doi:IMM3259 [pii] 10.1111/j.1365-2567.2010.03259.x. [PubMed: 20331470]

McKinstry KK, Strutt TM, Swain SL. Regulation of CD4+ T-cell contraction during pathogen challenge. Immunol Rev. 2010b; 236:110-124. doi:IMR921 [pii] 10.1111/j.1600-065X. 2010.00921.x. [PubMed: 20636812]

McKinstry KK, Strutt TM, Swain SL. Hallmarks of CD4 T cell immunity against influenza. J Intern Med. 2011; 269(5):507-518. doi:10.1111/j.1365-2796.2011.02367.x. [PubMed: 21362069]

Miotto HC, Couto BR, Goulart EM, Amaral CF, Moreira Mda C. Advanced Cardiac Life Support Courses: live actors do not improve training results compared with conventional manikins. Resuscitation. 2008; 76(2):244-248. doi:S0300-9572(07)00428-5 [pii] 10.1016/j.resuscitation. 2007.07.031. [PubMed: 17822830]

Moris P, van der Most R, Leroux-Roels I, Clement F, Drame M, Hanon E, Leroux-Roels GG, Van Mechelen M. H5N1 influenza vaccine formulated with AS03 A induces strong cross-reactive and polyfunctional CD4 T-cell responses. J Clin Immunol. 2011; 31(3):443-454. doi:10.1007/ s10875-010-9490-6. [PubMed: 21174144]

Nayak JL, Richards KA, Chaves FA, Sant AJ. Analyses of the specificity of CD4 T cells during the primary immune response to influenza virus reveals dramatic MHC-linked asymmetries in reactivity to individual viral proteins. Viral Immunol. 2010; 23(2):169-180. doi:10.1089/vim. 2009.0099. [PubMed: 20373997]

O' Donnell CD, Subbarao K. The contribution of animal models to the understanding of the host range and virulence of influenza A viruses. Microbes Infect. 2011; 13(5):502-515. doi:S1286-4579(11)00044-X [pii] 10.1016/j.micinf.2011.01.014. [PubMed: 21276869]

Palese, P.; Shaw, ML. Orthomyxoviridae: the viruses and their replication. In: Knipe, DM.; Howley, PM., editors. Fields Virology. 5th edn. Vol. vol 2. Lippincott Williams \& Wilkins; Philadelphia: 2007.

Pedersen GK, Madhun AS, Breakwell L, Hoschler K, Sjursen H, Pathirana RD, Goudsmit J, Cox RJ. T-helper 1 cells elicited by H5N1 vaccination predict seroprotection. J Infect Dis. 2012; 206(2): 158-166. doi:jis330 [pii] 10.1093/infdis/jis330. [PubMed: 22551811]

Perrone LA, Szretter KJ, Katz JM, Mizgerd JP, Tumpey TM. Mice lacking both TNF and IL-1 receptors exhibit reduced lung inflammation and delay in onset of death following infection with a 
highly virulent H5N1 virus. J Infect Dis. 2010; 202(8):1161-1170. doi:10.1086/656365. [PubMed: 20815704]

Plotkin SA. Vaccines: past, present and future. Nat Med. 2005; 11(4 Suppl):S5-11. doi:nm1209 [pii] 10.1038/nm1209. [PubMed: 15812490]

Powell TJ, Strutt T, Reome J, Hollenbaugh JA, Roberts AD, Woodland DL, Swain SL, Dutton RW. Priming with cold-adapted influenza A does not prevent infection but elicits long-lived protection against supralethal challenge with heterosubtypic virus. J Immunol. 2007; 178(2):1030-1038. doi: 178/2/1030 [pii]. [PubMed: 17202366]

Price GE, Huang L, Ou R, Zhang M, Moskophidis D. Perforin and Fas cytolytic pathways coordinately shape the selection and diversity of CD8+-T-cell escape variants of influenza virus. J Virol. 2005; 79(13):8545-8559. doi:79/13/8545 [pii] 10.1128/JVI.79.13.8545-8559.2005. [PubMed: 15956596]

Price GE, Ou R, Jiang H, Huang L, Moskophidis D. Viral escape by selection of cytotoxic T cellresistant variants in influenza A virus pneumonia. J Exp Med. 2000; 191(11):1853-1867. [PubMed: 10839802]

Price GE, Soboleski MR, Lo CY, Misplon JA, Quirion MR, Houser KV, Pearce MB, Pappas C, Tumpey TM, Epstein SL. Single-dose mucosal immunization with a candidate universal influenza vaccine provides rapid protection from virulent $\mathrm{H} 5 \mathrm{~N} 1, \mathrm{H} 3 \mathrm{~N} 2$ and $\mathrm{H} 1 \mathrm{~N} 1$ viruses. PLoS One. 2010; 5(10):e13162. doi:10.1371/journal.pone.0013162. [PubMed: 20976273]

Purwar R, Campbell J, Murphy G, Richards WG, Clark RA, Kupper TS. Resident memory T cells (T(RM)) are abundant in human lung: diversity, function, and antigen specificity. PLoS One. 2011; 6(1):e16245. doi:10.1371/journal.pone.0016245. [PubMed: 21298112]

Richards KA, Chaves FA, Alam S, Sant AJ. Trivalent inactivated influenza vaccines induce broad immunological reactivity to both internal virion components and influenza surface proteins. Vaccine. 2012 doi:S0264-410X(12)01485-5 [pii] 10.1016/j.vaccine.2012.10.039.

Richards KA, Chaves FA, Sant AJ. The memory phase of the CD4 T-cell response to influenza virus infection maintains its diverse antigen specificity. Immunology. 2011; 133(2):246-256. doi: 10.1111/j.1365-2567.2011.03435.x. [PubMed: 21517839]

Rimmelzwaan GF, Kuiken T, van Amerongen G, Bestebroer TM, Fouchier RA, Osterhaus AD. A primate model to study the pathogenesis of influenza A (H5N1) virus infection. Avian Dis. 2003; 47(3 Suppl):931-933. [PubMed: 14575089]

Roman E, Miller E, Harmsen A, Wiley J, Von Andrian UH, Huston G, Swain SL. CD4 effector T cell subsets in the response to influenza: heterogeneity, migration, and function. J Exp Med. 2002; 196(7):957-968. [PubMed: 12370257]

Salomon R, Hoffmann E, Webster RG. Inhibition of the cytokine response does not protect against lethal H5N1 influenza infection. Proc Natl Acad Sci U S A. 2007; 104(30):12479-12481. doi: 0705289104 [pii] 10.1073/pnas.0705289104. [PubMed: 17640882]

Scherle PA, Gerhard W. Functional analysis of influenza-specific helper T cell clones in vivo. T cells specific for internal viral proteins provide cognate help for B cell responses to hemagglutinin. J Exp Med. 1986; 164(4):1114-1128.

Schotsaert M, Saelens X, Leroux-Roels G. Influenza vaccines: T-cell responses deserve more attention. Expert Rev Vaccines. 2012; 11(8):949-962. doi:10.1586/erv.12.71. [PubMed: 23002976]

Schulman JL, Kilbourne ED. Induction of Partial Specific Heterotypic Immunity in Mice by a Single Infection with Influenza a Virus. J Bacteriol. 1965; 89:170-174. [PubMed: 14255658]

Scott B, Liblau R, Degermann S, Marconi LA, Ogata L, Caton AJ, McDevitt HO, Lo D. A role for non-MHC genetic polymorphism in susceptibility to spontaneous autoimmunity. Immunity. 1994; 1(1):73-83. doi:1074-7613(94)90011-6 [pii]. [PubMed: 7889402]

Seah SG, Carrington EM, Ng WC, Belz GT, Brady JL, Sutherland RM, Hancock MS, La Gruta NL, Brown LE, Turner SJ, Zhan Y, Lew AM. Unlike CD4+ T-cell help, CD28 costimulation is necessary for effective primary CD8+ T-cell influenza-specific immunity. Eur J Immunol. 2012; 42(7):1744-1754. doi:10.1002/eji.201142211. [PubMed: 22585421]

Seder RA, Ahmed R. Similarities and differences in CD4+ and CD8+ effector and memory T cell generation. Nat Immunol. 2003; 4(9):835-842. doi:10.1038/ni969 ni969 [pii]. [PubMed: 12942084] 
Seder RA, Darrah PA, Roederer M. T-cell quality in memory and protection: implications for vaccine design. Nat Rev Immunol. 2008; 8(4):247-258. doi:nri2274 [pii] 10.1038/nri2274. [PubMed: 18323851]

Selin LK, Wlodarczyk MF, Kraft AR, Nie S, Kenney LL, Puzone R, Celada F. Heterologous immunity: immunopathology, autoimmunity and protection during viral infections. Autoimmunity. 2011; 44(4):328-347. doi:10.3109/08916934.2011.523277. [PubMed: 21250837]

Sharma R, Sharma PR, Kim YC, Leitinger N, Lee JK, Fu SM, Ju ST. IL-2-controlled expression of multiple $\mathrm{T}$ cell trafficking genes and Th2 cytokines in the regulatory $\mathrm{T}$ cell-deficient scurfy mice: implication to multiorgan inflammation and control of skin and lung inflammation. J Immunol. 2011; 186(2):1268-1278. doi:jimmunol.1002677 [pii] 10.4049/jimmunol.1002677. [PubMed: 21169543]

Sheridan BS, Lefrancois L. Regional and mucosal memory T cells. Nat Immunol. 2011; 12(6):485491. [PubMed: 21739671]

Song K, Bolton DL, Wei CJ, Wilson RL, Camp JV, Bao S, Mattapallil JJ, Herzenberg LA, Andrews CA, Sadoff JC, Goudsmit J, Pau MG, Seder RA, Kozlowski PA, Nabel GJ, Roederer M, Rao SS. Genetic immunization in the lung induces potent local and systemic immune responses. Proc Natl Acad Sci U S A. 2010; 107(51):22213-22218. doi:1015536108 [pii] 10.1073/pnas.1015536108. [PubMed: 21135247]

Strutt TM, McKinstry KK, Dibble JP, Winchell C, Kuang Y, Curtis JD, Huston G, Dutton RW, Swain SL. Memory CD4+ T cells induce innate responses independently of pathogen. Nat Med. 2010; 16(5):558-564. 551. following 564. doi:nm.2142 [pii] 10.1038/nm.2142. [PubMed: 20436484]

Strutt TM, McKinstry KK, Kuang Y, Bradley LM, Swain SL. Memory CD4+ T-cell-mediated protection depends on secondary effectors that are distinct from and superior to primary effectors. Proc Natl Acad Sci U S A. 2012 doi:1205894109 [pii] 10.1073/pnas.1205894109.

Strutt TM, McKinstry KK, Swain SL. Control of innate immunity by memory CD4 T cells. Adv Exp Med Biol. 2011; 780:57-68. doi:10.1007/978-1-4419-5632-3_6. [PubMed: 21842365]

Suguitan AL Jr. McAuliffe J, Mills KL, Jin H, Duke G, Lu B, Luke CJ, Murphy B, Swayne DE, Kemble G, Subbarao K. Live, attenuated influenza A H5N1 candidate vaccines provide broad cross-protection in mice and ferrets. PLoS Med. 2006; 3(9):e360. doi:06-PLME-RA-0318R1 [pii] 10.1371/journal.pmed.0030360. [PubMed: 16968127]

Sun J, Madan R, Karp CL, Braciale TJ. Effector T cells control lung inflammation during acute influenza virus infection by producing IL-10. Nat Med. 2009; 15(3):277-284. doi:nm.1929 [pii] 10.1038/nm.1929. [PubMed: 19234462]

Sun K, Torres L, Metzger DW. A detrimental effect of interleukin-10 on protective pulmonary humoral immunity during primary influenza A virus infection. J Virol. 2010; 84(10):5007-5014. doi:JVI.02408-09 [pii] 10.1128/JVI.02408-09. [PubMed: 20200252]

Surls J, Nazarov-Stoica C, Kehl M, Olsen C, Casares S, Brumeanu TD. Increased membrane cholesterol in lymphocytes diverts T-cells toward an inflammatory response. PLoS One. 2012; 7(6):e38733. doi:10.1371/journal.pone.0038733 PONE-D-12-01985 [pii]. [PubMed: 22723880]

Swain SL, McKinstry KK, Strutt TM. Expanding roles for CD4(+) T cells in immunity to viruses. Nat Rev Immunol. 2012; 12(2):136-148. doi:nri3152 [pii] 10.1038/nri3152. [PubMed: 22266691]

Tate MD, Deng YM, Jones JE, Anderson GP, Brooks AG, Reading PC. Neutrophils ameliorate lung injury and the development of severe disease during influenza infection. J Immunol. 2009; 183(11):7441-7450. doi:jimmunol.0902497 [pii] 10.4049/jimmunol.0902497. [PubMed: 19917678]

Tate MD, Pickett DL, van Rooijen N, Brooks AG, Reading PC. Critical role of airway macrophages in modulating disease severity during influenza virus infection of mice. J Virol. 2010; 84(15):75697580. doi:JVI.00291-10 [pii] 10.1128/JVI.00291-10. [PubMed: 20504924]

Tate MD, Schilter HC, Brooks AG, Reading PC. Responses of mouse airway epithelial cells and alveolar macrophages to virulent and avirulent strains of influenza A virus. Viral Immunol. 2011; 24(2):77-88. doi:10.1089/vim.2010.0118. [PubMed: 21449718]

Taubenberger JK, Kash JC. Influenza virus evolution, host adaptation, and pandemic formation. Cell Host Microbe. 2010; 7(6):440-451. doi:S1931-3128(10)00172-1 [pii] 10.1016/j.chom. 2010.05.009. [PubMed: 20542248] 
Teijaro JR, Njau MN, Verhoeven D, Chandran S, Nadler SG, Hasday J, Farber DL. Costimulation modulation uncouples protection from immunopathology in memory $\mathrm{T}$ cell responses to influenza virus. J Immunol. 2009; 182(11):6834-6843. doi:182/11/6834 [pii] 10.4049/jimmunol. 0803860. [PubMed: 19454679]

Teijaro JR, Turner D, Pham Q, Wherry EJ, Lefrancois L, Farber DL. Cutting edge: Tissue-retentive lung memory CD4 T cells mediate optimal protection to respiratory virus infection. J Immunol. 2011; 187(11):5510-5514. doi:jimmunol.1102243 [pii] 10.4049/jimmunol.1102243. [PubMed: 22058417]

Teijaro JR, Verhoeven D, Page CA, Turner D, Farber DL. Memory CD4 T cells direct protective responses to influenza virus in the lungs through helper-independent mechanisms. J Virol. 2010; 84(18):9217-9226. doi:JVI.01069-10 [pii] 10.1128/JVI.01069-10. [PubMed: 20592069]

Thomas PG, Brown SA, Morris MY, Yue W, So J, Reynolds C, Webby RJ, Doherty PC. Physiological numbers of CD4+ T cells generate weak recall responses following influenza virus challenge. $\mathrm{J}$ Immunol. 2010; 184(4):1721-1727. doi:jimmunol.0901427 [pii] 10.4049/jimmunol.0901427. [PubMed: 20061406]

Treanor J. Influenza vaccine--outmaneuvering antigenic shift and drift. N Engl J Med. 2004; 350(3): 218-220. doi:10.1056/NEJMp038238 350/3/218 [pii]. [PubMed: 14724300]

Tripp RA, Sarawar SR, Doherty PC. Characteristics of the influenza virus-specific CD8+ T cell response in mice homozygous for disruption of the H-2lAb gene. J Immunol. 1995; 155(6):29552959. [PubMed: 7673713]

Waffarn EE, Baumgarth N. Protective B cell responses to flu--no fluke! J Immunol. 2011; 186(7): 3823-3829. doi:186/7/3823 [pii] 10.4049/jimmunol.1002090. [PubMed: 21422252]

Wei CJ, Boyington JC, McTamney PM, Kong WP, Pearce MB, Xu L, Andersen H, Rao S, Tumpey TM, Yang ZY, Nabel GJ. Induction of broadly neutralizing H1N1 influenza antibodies by vaccination. Science. 2010; 329(5995):1060-1064. doi:science.1192517 [pii] 10.1126/science. 1192517. [PubMed: 20647428]

Weinfurter JT, Brunner K, Capuano SV 3rd, Li C, Broman KW, Kawaoka Y, Friedrich TC. Crossreactive T cells are involved in rapid clearance of 2009 pandemic $\mathrm{H} 1 \mathrm{~N} 1$ influenza virus in nonhuman primates. PLoS Pathog. 2011; 7(11):e1002381. doi:10.1371/journal.ppat.1002381 PPATHOGENS-D-11-00455 [pii]. [PubMed: 22102819]

Wilkinson TM, Li CK, Chui CS, Huang AK, Perkins M, Liebner JC, Lambkin-Williams R, Gilbert A, Oxford J, Nicholas B, Staples KJ, Dong T, Douek DC, McMichael AJ, Xu XN. Preexisting influenza-specific CD4+ T cells correlate with disease protection against influenza challenge in humans. Nat Med. 2012; 18(2):274-280. doi:nm.2612 [pii] 10.1038/nm.2612. [PubMed: 22286307]

Xu L, Yoon H, Zhao MQ, Liu J, Ramana CV, Enelow RI. Cutting edge: pulmonary immunopathology mediated by antigen-specific expression of TNF-alpha by antiviral CD8+ T cells. J Immunol. 2004; 173(2):721-725. [PubMed: 15240656]

Yewdell JW. Viva la revolucion: rethinking influenza a virus antigenic drift. Curr Opin Virol. 2011; 1(3):177-183. doi:10.1016/j.coviro.2011.05.005. [PubMed: 22034587]

Yu X, Tsibane T, McGraw PA, House FS, Keefer CJ, Hicar MD, Tumpey TM, Pappas C, Perrone LA, Martinez O, Stevens J, Wilson IA, Aguilar PV, Altschuler EL, Basler CF, Crowe JE Jr. Neutralizing antibodies derived from the B cells of 1918 influenza pandemic survivors. Nature. 2008; 455(7212):532-536. doi:nature07231 [pii] 10.1038/nature07231. [PubMed: 18716625] 


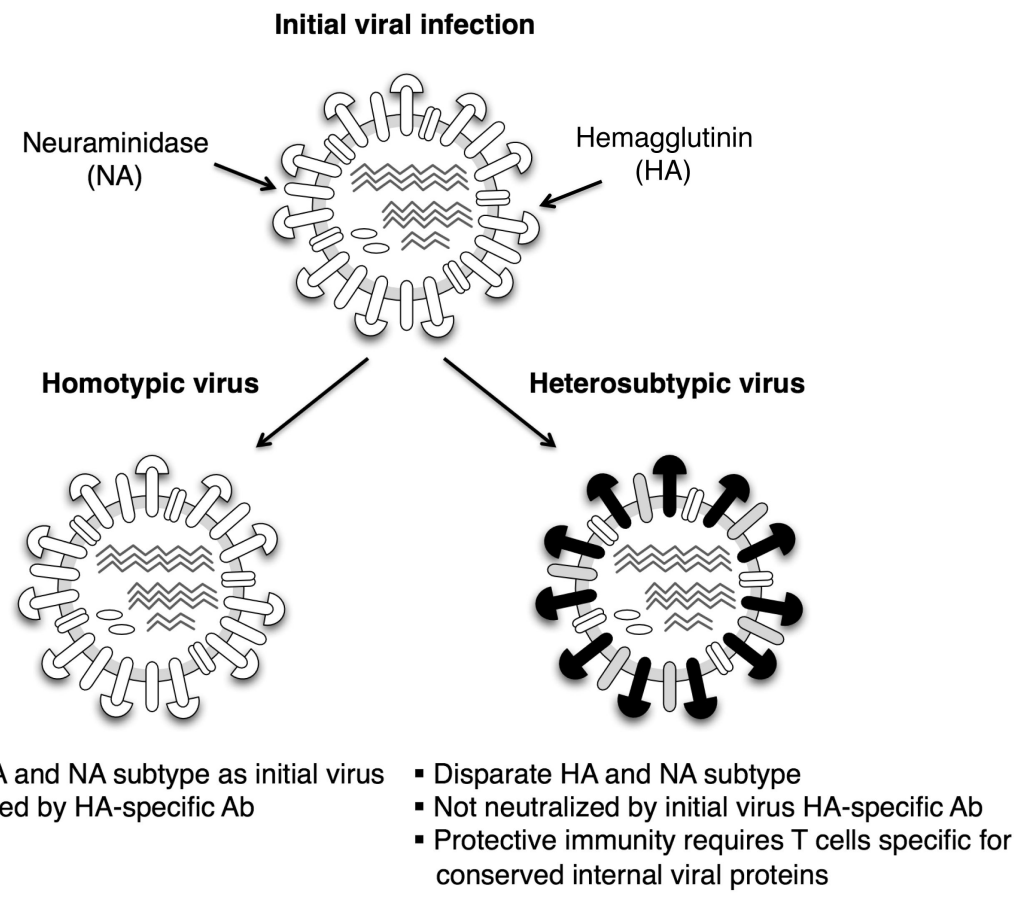

Figure 1.

Homotypic versus Heterosubtypic immunity against IAV. Homotypic immunity is mediated by neutralizing and protective antibodies generated upon infection or vaccination with a virus expressing the same external coat proteins (NA and HA). Heterosubtypic immunity is mediated largely by memory $\mathrm{T}$ cells that recognize internal viral proteins shared between the priming and challenge virus. 
Table 1

Deconstructing memory CD4 $\mathrm{T}$ cell protection against IAV

\begin{tabular}{ccc}
\hline $\begin{array}{c}\text { Adoptively-transferred } \\
\text { memory CD4 T cells }\end{array}$ & Unprimed host & $\begin{array}{c}\text { Memory CD4 T cell- } \\
\text { mediated protection }\end{array}$ \\
Wild-type & Wild-type & ++++
\end{tabular}


Table 2

The CD4 T cell response to IAV in unprimed hosts

\begin{tabular}{|c|c|c|}
\hline Functional attribute & $\underset{\text { effectors }}{\text { Primary CD4 T cell }}$ & $\begin{array}{c}\text { Secondary CD4 T cell } \\
\text { effectors }\end{array}$ \\
\hline $\begin{array}{l}\text { Enhancement of early } \\
\text { pulmonary inflammation }\end{array}$ & - & ++++ \\
\hline $\begin{array}{l}\text { Response magnitude in } \\
\operatorname{SLO}^{a}\end{array}$ & +++ & +++ \\
\hline Response magnitude in lung & +++ & +++++ \\
\hline $\begin{array}{l}\text { Multi-cytokine producing } \\
\text { potential } b\end{array}$ & +++ & +++++ \\
\hline IL-10 production & ++ & - \\
\hline IL-17 production & - & + \\
\hline $\begin{array}{l}\text { Protective capacity of SLO } \\
\text { effectors }\end{array}$ & + & +++ \\
\hline $\begin{array}{l}\text { Protective capacity of lung } \\
\text { effectors }\end{array}$ & +++ & +++++ \\
\hline TFH response in SLO & ++++ & ++++ \\
\hline TFH response in lung & - & ++ \\
\hline Cytotoxic response in SLO & - & - \\
\hline Cytotoxic response in lung & ++ & ++ \\
\hline
\end{tabular}

